\title{
Employing Women Technical Assistants for Enahncing the Empowerment of Women in Scoiety
}

\author{
Anudevi, V. Sailaja, S. Binapani
}

\begin{abstract}
Women in India have historically been suppressed and even more repressed have been women in particular who belong to the economically and socially weaker sections of society. Throughout post-independence India, all the provisions in the constitution and the length of legislation enacted to empower women were not sufficient to free women from their conventional bondages, liabilities and restrictions. The involvement of women in decision-making processes, particularly in rural areas, has remained very marginal until recent times. This article highlights the satisfaction of members in Tamilnadu for marketing women's self-help groups.
\end{abstract}

Keywords: Self-Help Groups (SHGs), Marketing Activities, Marketing Products, Marketing Performance, SHG Members Satisfaction and Experience

\section{INTRODUCTION}

A Self-Help Group (SHG) is a registered or unregistered group of micro-entrepreneurs with homogeneous social and economic backgrounds, who come together on a voluntary basis to save regular small sums of money, agree to contribute to a common fund and meet their emergency needs on a mutual basis.

The programs also implemented a unique concept in each self-help group to encourage master farmers to take practical leadership in activities related to development, marketing and credit. Farmers receive training in crop production engineering, industrial development and management of enterprises[1]-[3]. Training programs are structured on the basis of need to be defined and appropriate training modules are used. Through Participatory Technology Development, the programs introduced a new methodology of appropriate technology. Farmers experiment with on-farm experiments to develop better technologies and adapt existing technologies that incorporate the latest scientific expertise in the field of fiber

\section{A. Self-Help Groups}

Revised Manuscript Received on December 11, 2019

Anudevi, Department of Science and Humanities, Bharath Institute of Higher Education and Research, Chennai , India. Email: Anudevi28@gmail.com

V. Sailaja, Department of Science and Humanities, Bharath Institute of Higher Education and Research, Chennai , India. Email: psaillajagmail.com

S. Binapani, Department of Science and Humanities, Bharath Institute of Higher Education and Research, Chennai, India. Email: bina.saravanangmail.com
It is a rural women's group with at least 20 members involved in savings, internal lending, micro-entrepreneurial activities, assimilation and dissertation of health, childcare, education, woman's participation in household decision-making, and so on[4]-[5].

\section{REVIEW OF LITERATURE}

Tripathy (2004) conferred SHGs ' dynamic position in rural expansion by saying that SHGs are tools for improving society, stimulating the economy, structuring entrepreneurship, and group solidarity. The writer noted that the SHGs offer a great opportunity for different services to be consulted[6]-[9].

Ravindra (2010) The launch of self-help groups in India was outlined and the quality of the SHGs was evaluated along with SHG-Bank Linkage's growth over the years. He also conferred on the issues faced by the SHGs such as participants ' analphabetism, lack of proper management, dual funding, high interest rates on bank loans, 63 low-tech issues, advertising issues, etc.

\section{DATA COLLECTION AND ANALYSIS}

The work was carried out in the Kanchipuram districts and Chennai districts. Therefore, the list of all the SHGs from the selected blocks of district procured for the investigation. The census method was used to select the SHGs from the selected blocks.

Investigator tried to contact the entire SHGs member however due to some reasons the total number of women members of SHGs contacted from selected districts were 198. Some of the respondents could not be contacted as they were not available at the time of interview[10]-[13]. Observation, focused group discussion and case study method were also used to support the quantitative data. Analysis of the data was done with the help of different statistical tool like frequency distribution, percentage, mean, standard deviation, weighted mean score, correlation coefficient(r) as well as multiple linear regressions.

\section{RESULTS AND DISCUSSION}

The members experience in their occupation plays a vital role in the productivity of their products which in turn increases the marketable surplus. Also based on their

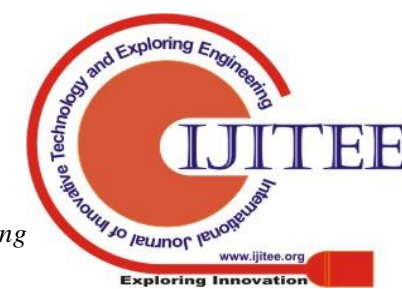


experience and expertise, they choose the disposal point, marketing channel and the time of disposal which are all very important for this study.

\begin{tabular}{|l|c|c|}
\hline \multicolumn{1}{|c|}{ Year } & No. of Members & Percentage \\
\hline Up to 2 years & 150 & 30 \\
\hline $3-5$ years & 270 & 54 \\
\hline 6 years and above & 80 & 16 \\
\hline \multicolumn{1}{|c|}{ Total } & $\mathbf{5 0 0}$ & 100 \\
\hline
\end{tabular}

Table - 2 Member in the SHG

It is noted from the table 2 shows that 270 ( 54 per cent) of the total respondents have 3-5 years' experience in marketing of SHG products. Out of total 150 (30 per cent) of the respondents have upto 2 years' experience and only 80 (16 per cent) sample respondents have more than 6 years. As majority of respondents (270) have 3-5 years' experience the opinion expressed by them will be worth for the study.

\begin{tabular}{|l|c|c|}
\hline \multicolumn{1}{|c|}{ Particulars } & No. of Members & Percentage \\
\hline Self & 55 & 11 \\
\hline Group leader & 75 & 15 \\
\hline Familymembers & 100 & 20 \\
\hline Friends and Relatives & 225 & 45 \\
\hline NGO & 45 & 09 \\
\hline \multicolumn{1}{|c|}{ Total } & 500 & 100 \\
\hline
\end{tabular}

Table - 3 Influenced to Join the SHGs

The Table 3 depicts that majority of the SHG members joined through their friends and relatives which shows 45 per cent and 20 per cent of the members joined through their family members. From the study that 15 per cent of the sample respondents motivated by group leaders to join the SHG and 11 per cent of them self-interested to join the group. Among the sample respondents only 9 per cent of the members are joined through the NGO.

\begin{tabular}{|c|c|c|}
\hline Role in the SHGs & No. of Nembers & Percentage \\
\hline Animator & 25 & 05 \\
\hline Representative & 75 & 15 \\
\hline Meaber & 400 & 80 \\
\hline Total & 500 & 100 \\
\hline Source: Primary data
\end{tabular}

Table - 4 Role in the SHGs

According to the study, the majority of respondents ' role in the SHG is members, showing that $80 \%$ and $15 \%$ of sample respondents are representatives and only $5 \%$ are animators.

\begin{tabular}{|c|c|c|}
\hline Particulars & No. of Mem bers & Percentage \\
\hline Yes & 400 & 80 \\
\hline No & 100 & 20 \\
\hline Total & $\mathbf{5 0 0}$ & $\mathbf{1 0 0}$ \\
\hline
\end{tabular}

Table - 5 Group Meetings

Most sample respondents ' opined that for their cultivation they have their own pump sets. Of the 400 (80\%) respondents, only 100 respondents $(20 \%)$ have their own pump sets for cultivation and the rest of them do not have their own pump sets for cultivation.

\begin{tabular}{|c|c|c|}
\hline Particulars & No. of Members & Percentage \\
\hline Monthly & 200 & 50 \\
\hline Fornightly & 80 & 20 \\
\hline Weekly & 120 & 30 \\
\hline Total & 400 & 100 \\
\hline
\end{tabular}

Table - 6 Frequency of Meeting

Table 6 indicates that most survey respondents are of the opinion that meetings are held on a monthly basis once that is 200 (50 percent) and that out of the total 120 (30 percent) respondents are of the opinion that meetings are held once a week. Just 50 ( 20 percent) of the survey respondents decided that meetings would take place every fortnight.

\begin{tabular}{|c|c|c|}
\hline Particulars & No. of Members & Percentage \\
\hline Regularly & 350 & 70 \\
\hline Occasionally & 100 & 20 \\
\hline Rarely & 30 & 06 \\
\hline Not attending the meting & 20 & 04 \\
\hline Total & 500 & 100 \\
\hline
\end{tabular}

Table 7: Meetings attended by the Members

According to Table 7 about the meetings attended by the SHG member, most of the survey respondents are of the opinion that they regularly attend a meeting that indicates $70 \%$ and $20 \%$ of the participants are of the opinion that they rarely attend. $4 \%$ of the sample members are not interested in attending the conferences, and only $6 \%$ of the participants seldom participate.

\begin{tabular}{|c|c|c|}
\hline Particulars & No. of Members & Percentage \\
\hline Yes & 450 & 90 \\
\hline No & 50 & 10 \\
\hline Total & $\mathbf{5 0 0}$ & $\mathbf{1 0 0}$ \\
\hline
\end{tabular}

Table 8: Members Co-operative and Social mind

\begin{tabular}{|c|c|c|l|c|}
\hline & \multicolumn{2}{|c|}{$\begin{array}{l}\text { After } \\
\text { Joining } \\
\text { the }\end{array}$} & \\
Income & $\begin{array}{c}\text { Before Joining } \\
\text { the SHG }\end{array}$ & Percentage & PHG & \\
\hline No earning & & 5.00 & & 5.00 \\
\hline Insufficient & & 60.00 & & 12.00 \\
\hline Sufficient & & 30.00 & & 63.00 \\
\hline Surplus & & 4.00 & & 20.00 \\
\hline Total & $\mathbf{0}$ & $\mathbf{1 0 0 . 0 0}$ & & $\mathbf{5 0 0}$ \\
\hline
\end{tabular}

Table - 9 Feeling On Earnings

The majority of the respondents gives their opinion that their earnings is not sufficient in before joining the SHG which constitutes 353 (66.10 per cent) out of 534. From the above analysis 29.03 per cent of them agreed that their earnings are sufficient before joining the SHG. 3.00 per cent of the assenters are in the category of no earnings and only 1.87 per cent of them earnings are surplus after expended the family expenses[14]-[17]. 
The table depicts that most of the sample respondents agreed their earnings are sufficient after joining the SHG which shows that the 339 (63.48 per cent) and 99 (18.54 per cent) sample members earnings is surplus. Among the members 67 (12.55 per cent) those earnings are insufficient and only 29 (5.43 per cent) respondents not earned any income after joining the SHG.

\begin{tabular}{|c|c|c|}
\hline Particulars & No. of Members & Percentage \\
\hline Yes & 375 & 75 \\
\hline No & 125 & 25 \\
\hline Total & $\mathbf{5 0 0}$ & $\mathbf{1 0 0}$ \\
\hline
\end{tabular}

Table 10: Economic Status improved after Joining in

\section{SHGs}

From the review of the above table, the majority of sample employers accepted that their economic status had improved since joining the SHGs, showing 375 (75\%) and the remaining economic status of the total of 125 (25\%) respondents.

\begin{tabular}{|c|c|c|}
\hline Particulars & No of Mem bers & Percentage \\
\hline Yes & 139 & 26.03 \\
\hline No & 395 & 73.97 \\
\hline Total & 534 & 100 \\
\hline
\end{tabular}

\section{Table 11: Savings accounts of the Respondents}

Table 11 shows that the majority of survey respondents do not hold a savings account of 73.97 percent and the remainder of them have a 26.03 percent balance. The table above clearly indicates that there is no savings account for most participants. In addition, it is recommended that the sample participants open the savings account[18]-[20].

\begin{tabular}{|c|c|c|}
\hline Particulars & No. of Members & Percentage \\
\hline Post Office & 19 & 13.67 \\
\hline Co-operative bank & 3 & 2.16 \\
\hline Commercial Banks & 112 & 80.58 \\
\hline Chit Funds & 5 & 3.60 \\
\hline Total & 139 & $\mathbf{1 0 0}$ \\
\hline
\end{tabular}

Table 12: Name of the Institution

Table 12 shows that the majority of survey respondents who have a savings account in commercial banks were $80.58 \%$ and $13.67 \%$ of respondents who have such accounts with the post office. Of the study, $3.60 \%$ of the members have chit funds accounts and only $2.16 \%$ have cooperative bank accounts. The table above clearly shows that most sample members in commercial banks have a savings account.

\begin{tabular}{|l|c|c|}
\hline \multicolumn{1}{|c|}{ Particulars } & No of Members & Percentage \\
\hline Personal canvass & 300 & 60 \\
\hline NGO /Govemment & 100 & 20 \\
\hline Middleman & 25 & 05 \\
\hline Directly to the customer in shop $\quad 75$ & 15 \\
\hline \multicolumn{1}{|c|}{ Total } & 7500 & 100 \\
\hline
\end{tabular}

Table 13: Marketing of the Products

Table 13 indicates that most SHG leaders are of the opinion that they are doing personal canvas to market their products, which reveals $60 \%$ and $20 \%$ of them are selling their goods through the NGO / Government. It is noticed that $15 \%$ of them sell their products directly to the consumer in the shop and only $5 \%$ of the SHGs sell their products through the intermediary.

\begin{tabular}{|c|c|c|}
\hline Particulars & No. of Members & Percentage \\
\hline Yes & 190 & 38 \\
\hline No & 310 & 62 \\
\hline Total & 500 & 100 \\
\hline
\end{tabular}

Table 13: Entrepreneurship Training

Table 13 indicates that most employers decided that they are not attending any entrepreneurial training which shows 62 percent and 38 percent of participants are attending such training.

\begin{tabular}{|l|c|c|}
\hline \multicolumn{1}{|c|}{ Name of the Training } & No. of Members & Percentage \\
\hline Training on industrializing of catering. pidckes and pepped & 73 & 39 \\
\hline Training on skill development & 05 & 02 \\
\hline Tailoring and readymade garments & 29 & 15 \\
\hline Training on beauty parlour management & 27 & 14 \\
\hline Dairy farming & 07 & 04 \\
\hline Handicraft works, toys making, rexin bag preparations & ${ }^{4}$ & 26 \\
\hline \multicolumn{1}{|c|}{ Total } & 190 & 100 \\
\hline
\end{tabular}

Table 14: Type of Training

The Table 14 displays only 190 are attended the entrepreneurship training out of the sample of 500. Most of the survey respondents were attended from the study in the catering, pickle and pepper manufacturing school, which represents 39 percent of the total. The Handicraft works, toys making, rexin bag preparations and Tailoring and readymade garments constitutes 26 per cent and 15 per cent respectively. Further it reveals that Training on beauty parlour management shows 14 per cent and Dairy farming indicates 4 per cent correspondingly. Ultimately, $2 \%$ of the survey respondents completed skill development training that demonstrated the least proportion of the above study.

\begin{tabular}{|l|c|c|c|}
\hline \multicolumn{1}{|c|}{ Factors } & N & Mean Score & Rank \\
\hline To Improve the Social Status & 500 & 5.19 & VII \\
\hline To Promote Savings Habit & 500 & 4.13 & IX \\
\hline To Obtain Financial Support & 500 & 5.96 & VI \\
\hline To Initiate Group Activities & 500 & 8.16 & I \\
\hline Easy Avalability of Credit & 500 & 4.77 & VII \\
\hline Lack of Permanent Job for Husband & 500 & 7.09 & III \\
\hline To support the Family & 500 & 7.21 & II \\
\hline Permanentijob availabbility & 500 & 6.28 & V \\
\hline Modivated by Friends & 500 & 6.32 & IV \\
\hline
\end{tabular}

Table 15: Reason for Joining SHGs (Rank Analysis)

Table 15 reveals that the reason for joining SHGs to undertake group activities ranks first the mean value $=8.16$ and the standard deviation value $=2.475$ followed by the help of the mean value family $=7.21$ and the standard deviation value $=2.980$, the lack of permanent employment for the mean value husband $=3.98$ and the standard deviation value $=1.127$, the loss of crops due to the mean value of livestock=7.09 and st. motivated by friends of mean value $=6.32$ and standard deviation value $=3.312$, permanent job availability of mean value $=6.28$ and standard deviation value $=2.844$, to obtain financial support of mean value $=5.96$ and standard deviation value $=2.566$, to improve the social status of mean value $=5.19$ and standard deviation value $=3.194$, mean value $=4.77$ and standard deviation value $=3.211$ and finally to promote savings

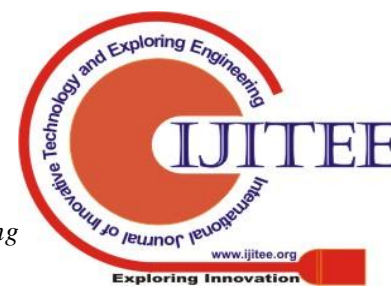


habit of mean value $=4.13$ and standard deviation value $=$ 3.261 , It is therefore concluded the reason for joining SHGs to initiate group activities in the first rank, mean value $=8.16$ and standard deviation value $=2.475$ followed by enhancing the last and eleventh rank of earning capacity, mean value $=3.96$ and standard deviation value $=2.382$.

\section{SUGGESTIONS}

Governments may also hold such trade fairs solely for SHG products and supply the products to the market. If they can get international orders, resolving the balance of pay deficits will also be useful.

The level of rural women's literacy is low and therefore priority should be given to efforts to improve the level of literacy in the area[21]-[23].

This revolutionary concept can be applied globally and the majority of SHGs can benefit from simple advertising.

Financing banks can take the lead in providing marketing training to SHG members, thereby encouraging them to develop their own marketing strategies for their products. In addition, this will also protect their capital base by increasing banks ' NPAs

Types of workshops are a rare phenomenon and may be conducted in a district-wise manner in order to educate the SHG members in marketing, which in turn would boost the marketing of SHG goods.

Members must receive some kind of training in order to properly educate themselves on the use of capital.

Advertisement in magazines, newspapers, television and movies should be used to increase public perception of the services of SHGs. The government will subsidize a portion of this spending.

Responses to scheme knowledge, knowledge of rights and privileges, knowledge of growth, knowledge of employability and knowledge of integration and survival by SHG members indicate that members are highly satisfied with the resulting empowerment[24]-[25].

\section{CONCLUSION}

This article concludes that advertising is made easy for SHGs, the tactics and the inculcation of adequate knowledge of the markets and competitors. Once the SHGs get the fruits of easy advertising, they will definitely participate in more development at lower costs and one day they will also be able to become global players. Since most villagers are engaged in one or the other SHG activity, engaging them in business promotion and opening up the gates of global markets for them will improve the country's economy and improve our payment balance positions. In a globalized economy, this will make our country a leader. The study further finds that participation of women is a main ingredient for the successful empowerment. The study accepts all the four levels that greater participation of women in the project leads

to greater levels of empowerment at the individual, household, self-help group/enterprise and community level.

\section{REFERENCES}

1. Vasanthi, S. \& Rabiyathul Basariya, S. 2019, "Influence of value analysis and cross training in industry", International Journal of Engineering and Advanced Technology, vol. 8, no. 6, pp. 1810-1811

2. Velvizhi, R., Sri Gowtham, S. \& Jeya Priya, D. 2019, "Examination of early feedbacks for effective product retailing on E-commerce websites", International Journal of Engineering and Advanced Technology, vol. 8, no. 6 Special Issue 2, pp. 703-706.

3. Anuradha, C., Pothumani, S. \& Kavitha, R. 2019, "A novel method towards E-commerce", International Journal of Engineering and Advanced Technology, vol. 8, no. 6 Special Issue 2, pp. 535-538.

4. Thomas, J. \& Rabiyathul Basariya, S. 2019, "A study on the issues of financial ratio analysis", Indian Journal of Public Health Research and Development, vol. 10, no. 3, pp. 1079-1081.

5. Ramachandran, S. \& Rabiyathul Basariya, S. 2019, "Online marketing study on customer satisfaction and relationship", Indian Journal of Public Health Research and Development, vol. 10, no. 3, pp. 1072-1078.

6. Priya, R., Vinothini, G. \& Cor Jesu, C.D. 2019, "The mentor-protégé relationship for professional growth", Journal of Advanced Research in Dynamical and Control Systems, vol. 11, no. 9 Special Issue, pp. 1110-1119.

7. Jannifer Rani, N., Bina Pani, S. \& Nimisha, N.S. 2019, "A study on money back polices available in LIC", Journal of Advanced Research in Dynamical and Control Systems, vol. 11, no. 9 Special Issue, pp. 833-839.

8. Saillaja, V., Jhansi Rani, K. \& Catherine, R. 2019, "Global marketing management planning and organization", Journal of Advanced Research in Dynamical and Control Systems, vol. 11, no. 9 Special Issue, pp. 489-493.

9. Saillaja, V., Jhansi Rani, K. \& Catherine, R. 2019, "The new phase of marketing information system", Journal of Advanced Research in Dynamical and Control Systems, vol. 11, no. 9 Special Issue, pp. $482-488$.

10. Thoufiqulla \& Raju, D.V. 2019, "Perception of indian investor towards investment in mutual funds with special reference to mip funds", Journal of Advanced Research in Dynamical and Control Systems, vol. 11, no. 5, pp. 177-183.

11. Jasmine, K.R.M. \& Basariya, S.R. 2018, "A study on the customers benefits on mutual funds", International Journal of Civil Engineering and Technology, vol. 9, no. 4, pp. 45-48

12. Vasanthi, S. \& Basariya, S.R. 2019, "Pros and cons of on the job training versus off the job training", International Journal of Scientific and Technology Research, vol. 8, no. 10, pp. 671-674.

13. Pavithra, J. \& Ganesan, M. 2016, "A study on awareness and impact of micro-financial schemes", International Journal of Applied Business and Economic Research, vol. 14, no. 8, pp. 5449-5460.

14. Pavithra, J., Dilli Babu, P. \& Ambuli, T.V. 2014, "A study on budgetary control at Maruti Service Masters, Chennai", International Journal of Applied Business and Economic Research, vol. 12, no. 2, pp. 151-161.

15. Gunaraja, T.M. \& Venkatrama Raju, D. 2018, "Determining factors of organisational climate with reference to leadership styles", International Journal of Mechanical Engineering and Technology, vol. 9, no. 9, pp. 1327-1332.

16. Gunaraja, T.M. \& Venkatrama Raju, D. 2018, "The role of job satisfaction and training of employees in determining organisational climate of a selected industry", International Journal of Civil Engineering and Technology, vol. 9, no. 8, pp. 1266-1269.

17. Aarathy, T.S. \& Raju, D.V. 2018, "Performance appraisal and its effects on employees with respect to it sector in Chennai city", International Journal of Civil Engineering and Technology, vol. 9, no. 6, pp. 1535-1538.

18. Aarathy, T.S. \& Raju, D.V. 2018, "Employee perception towards performance appraisal system in IT sector", International Journal of Mechanical Engineering and Technology, vol. 9, no. 5, pp. 131-135.

19. Porselvi, W., Jublee, D. \& Sivanesan, G. 2018, "A study on factors influencing adoption of technology and innovation in banking industry, tamilnadu, India", International Journal of Mechanical Engineering and Technology, vol. 9, no. 5, pp. 789-800.

20. Akessa, G.M. and Dhufera, A.G., 2015. Factors That Influences Students Academic Performance: A Case of Rift Valley University, Jimma, Ethiopia. Journal of Education and Practice, 6(22), pp.55-63. 
21. Miller, G. and Shih, C.C., 1999. A faculty assessment of the academic rigor of on-and off-campus courses in agriculture. Journal of Agricultural Education, 40, pp.57-65.

22. Tsinidou, M., Gerogiannis, V. and Fitsilis, P., 2010. Evaluation of the factors that determine quality in higher education: an empirical study. Quality Assurance in education, 18(3), pp.227-244.

23. Farooq, M.S., Chaudhry, A.H., Shafiq, M. and Berhanu, G., 2011. Factors affecting students' quality of academic performance: a case of secondary school level. Journal of quality and technology management, 7(2), pp.1-14.

24. Fitsilis, P., Gerogiannis, V. and Anthopoulos, L., 2014. Ontologies for software project management: a review. Journal of Software Engineering and Applications, 7(13), p.1096.

25. Adams, J.D. and Jaffe, A.B., 1996. Bounding the effects of R\&D: an investigation using matched establishment-firm data(No. w5544). National bureau of economic research.

\section{AUTHORS PROFILE}

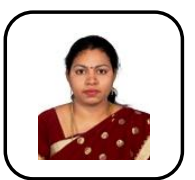

Anudevi Assistant Professor, Department of Science and Humanitiess, Bharath Institute of Higher Education and Research, Chennai, India.

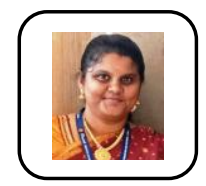

V.Sailaja Assistant Professor, Department of Science and Humanities, Bharath Institute of Higher Education and Research, Chennai, India.

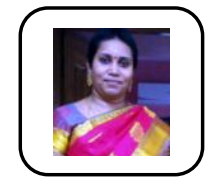

S.Binapani Assistant Professor, Department of Science and Humanities, Bharath Institute of Higher Education and Research, Chennai, India. 